\title{
The Local Use of Section 136
}

Malcolm P. I. Weller, Consultant Psychiatrist, Friern Hospital; Ben G. A. Weller, schoolboy, St Paul's School (now Faculty of Law, University of Birmingham); SEAN BAUMANN, Registrar, Friern Hospital and E. COKER, SHO, Friern Hospital, London N11

Recent attention has been focused on divergent practices in the implementation of Section $136,{ }^{1}$ problems in its practice encountered by the police, ${ }^{2}$ and possible means of improving the service and reducing unnecessary detention. ${ }^{3}$ In these studies, doubts have been raised about the justness of the section, both in principle and in practice, and about the efficiency and efficacy of its implementation. In the context of the closure of the large psychiatric institutions it seems probable that these issues will become increasingly acute. The purpose of our brief study was therefore to investigate the trends of admissions to Friern Hospital, not only of patients under Section 136, but of all patients accompanied by the police.

It might be expected that the run-down of Friern Hospital would be accompanied by a significant rise in the number of disturbances dictating a section 136 , since the pool of mentally unwell within its catchment districts (Camden, Bloomsbury, Islington and Haringey) will presumably have increased. To determine the number of section 136 admissions over the 16 year time period (1970-1986) the hospitals admission records were examined but due to the size of the task and the relative inaccessibility of old records, a sample of only 11 years was taken $(1970,1973,1975,1976$, $1977,1978,1980,1983,1985,1986$ and January to August 1987).

The findings are displayed graphically plotted against time and the best fit linear regression superimposed, using the method of least square.

Number of Patients Admitted into Friern Hospital under Section 136 of the Mental Health Acts of 1959 and 1983

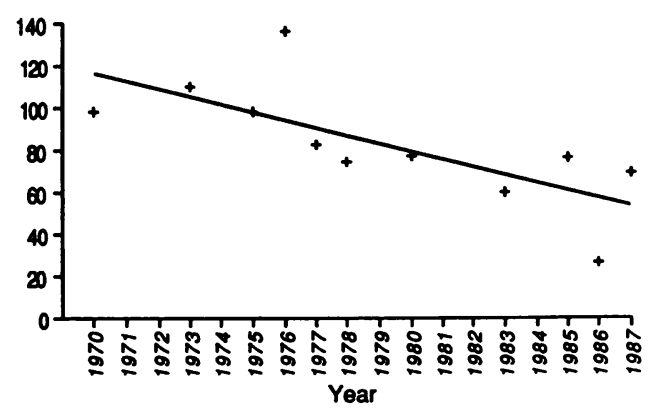

The final figure has been adjusted to encompass a 12 month epoch, which is comparable to the total number of patients admitted over the 12 month period August 19861987. This shows a significant decrease in the number of section 136 admissions to Friern Hospital over the study period ( $\mathrm{r}=0.749 ; P<0.01$ two-tailed).

This finding runs counter to expectations on the basis that an increasing proportion of psychiatric patients are being discharged from in-patient psychiatric care and known to be often faring badly. The results prompted us to keep records of all admissions, prospectively from August 1986 over a 12 month period, to one psychiatric firm in which the police accompanied the patient. Out of 44 patients so admitted one was brought in under section 4 of the 1983 Act and one under section 2, one under section 48, 20 were brought in under section 136 and 21 without any documentation. All the patients were seriously disturbed and deemed to merit observation.

The Mental Health Act Commissioners have repeatedly stressed that an exceptionally large number of patients are admitted to Friern Hospital under section 136 and have claimed that the number is the greatest in the country. These assertions have been communicated critically, with the implication that this is unsatisfactory and reflects badly on the hospital, despite the fact that such admissions in the past have been shown to consist of particularly disturbed individuals. ${ }^{4}$

Friern serves four London districts that incorporate a number of inner city areas to which the mentally ill gravitate, generating an exceptional concentration of psychosis. It is not surprising, therefore, that many patients are brought to the hospital by the police. What is surprising is that the numbers show a significant decline which is reflected in the statistics of the country (England) as a whole-1835 in 1985 to 1524 in 1986 , having been static until then, with a similar picture in the NE Thames District Health Authority - 539 in 1985 falling to 431 in 1986, while the number of long-stay patients has reduced.

However, the decline in such admissions may reflect a tendency to adopt other avenues of disposal such as police and prison cells or a change in administrative practice. Individuals brought by the police generally were very disturbed, and there was no discernible difference in those brought by the police on a section of the Mental Health Act and those brought without any documentation. Certainly on all occasions recorded here the circumstances amply warranted admission. However, we were dealing with a 
biased population in which the patient was actually admitted. Discussions with colleagues and our experience on night and weekend duty lead us to believe, in accord with Bean's review, ${ }^{\mathbf{5}}$ that the police were prescient in their diagnoses of mental illness and seldom diagnosed inappropriately or when the severity was slight. On the contrary, we felt that if the police were guilty of error it was likely to be to under use their powers in this regard.

The impact of the reductions in the long-stay psychiatric patient population and psychiatric hospital closures is evident in other data, such as the prison population, ${ }^{6}$ violent offences, destitution ${ }^{7.8}$ and wandering, ${ }^{9}$ but may be masked in the statistics of section 136 admissions if the police accompany patients to hospital without using statutory instruments, seeming instead to be prepared to exercise a benign paternalism. In one case the patient was brought to a local district general hospital on a section 136 in handcuffs and was transferred from there to Friern Hospital as a 'voluntary' patient, a situation that was stressed, no doubt, because it is debatable whether section 136 provides authority to transfer patients from one place of safety to another.

ACKNOWLEDGEMENTS

'We thank the Friern Hospital Library, Mr A. Cook and
Mrs M. Murphy for help with medical records, and May \& Baker for financial assistance.'

\section{REFERENCES}

${ }^{1}$ Rassaby, E. \& Rogers, A. (1987) Psychiatric referrals from the police: variations in disposal at different places of safety. Bulletin of the Royal College of Psychiatrists, 11, 79-81.

2DUNN, J. \& FAHY, T. (1987) Section 136 and the police. Bulletin of the Royal College of Psychiatrists, 11, 224-226.

${ }^{3}$ BAXTER, S. (1987) Section 136. Bulletin of the Royal College of Psychiatrists, 11, 274.

4Szmukler, G. I., Gird, A. F. \& Button, E. J. (1981) Compulsory admission in a London Borough. Pts 1 and 2. Psychological Medicine, 2, 617-636 and 825-838.

${ }^{5}$ BeAN, P. (1980) Compulsory Admission to Mental Hospitals, Chichester: John Wiley, p. 73.

${ }^{6}$ Weller, M. P. I. \& Weller, B. G. A. (1986) Crime and psychopathology (letter) British Medical Journal, 289, 2-3.

${ }^{7}$ Weller, B. G. A. \& Weller, M. P. I. (1986) Health care in a destitute population: Christmas 1985. Bulletin of the Royal College of Psychiatrists, 10, 233-235.

8 _ _ COKER, E. \& MAHOMED, S. (1987) Crisis at Christmas 1986. Lancet, March 7, 553-554.

${ }^{9}$ Weller, M. P. I. \& Jaurer, P. (1987) Wandering at Heathrow Airport. Medicine Science and Law, 27, 37-39.

\section{New Publications}

Behavioural Neurology is a new quarterly which will publish mainly clinical papers dealing with disordered human behaviour covering the fields of organic and biological psychiatry, clinical neuropsychology and neurological disorders of the cerebral cortex. The editor is Dr Andrew Lees, The National Hospital for Nervous Diseases, Queen Square, London WC1 3BG and it is published by CNS Publishers, 50 Ferry Street, London E14 9DT.

Elsevier Science Publishers, 91 rue de Rennes, F-75006, Paris, France have agreed to publish and distribute Psychiatry and Psychobiology which was originally launched in 1986. Results of clinical studies related to natural history and psychopathological disorders, and results of therapeutic studies such as investigation of pharmacological therapies effects are included, as well as animal model, socioepidemiological, biological and psychological studies.

Following the paper given by Dr J. Marks of Halton General Hospital at the Spring Quarterly Meeting 1988 on desensitisation by paradoxical intention (DPI) and the community psychiatric nurse management of benzodiazepine addiction, copies of the booklet for patients entitled Understanding Panics may be obtained from Paul Sturgeon, RMN, Halton General Hospital, East Lane, Runcorn, Cheshire WA7 2DA (telephone 0928 714567).

\section{New Course}

The University of Kent at Canterbury is offering a course leading to an MA in Psychoanalytic Studies, the first of its kind in Great Britain. It is designed to appeal to students who wish to study the broader cultural applications of psychoanalysis, as well as the status of its theoretical work; the course does not support a particular psychoanalytical viewpoint.

Applicants without direct experience of psychoanalysis or psychoanalytic therapy will be offered the possibility to consult qualified practitioners, should they wish to begin analysis or therapy as a background experience. It is stressed that this course does not provide a qualification to practise psychoanalysis.

There are two core courses: The Psychoanalytic Movement and Concepts of Psychoanalysis.

Further information and application forms: $\mathrm{Dr} \mathbf{M}$. Stanton, Eliot College, The University, Canterbury, Kent CT2 7NS (telephone 0227 764000, fax 0227 459025). 